\author{
Asian Journal of \\ Medical and Biological Research \\ ISSN 2411-4472 (Print) 2412-5571 (Online) \\ www.ebupress.com/journal/ajmbr
}

\title{
Article \\ Testing purity of commonly used marketed insecticides collected from different regions of Bangladesh
}

\author{
Md. Sultan Ahmed ${ }^{1}$, Md. Mohsin Ali Sardar ${ }^{2}$, Masum Ahmad ${ }^{2}$ and Kamal Humayun Kabir ${ }^{1}$ \\ ${ }^{1}$ Division of Entomology, Bangladesh Agricultural Research Institute, Joydebpur, Gazipur-1701, Bangladesh \\ ${ }^{2}$ Department of Entomology, Bangladesh Agricultural University, Mymensingh-2202, Bangladesh
}

*Corresponding author: Md. Sultan Ahmed, Division of Entomology, Bangladesh Agricultural Research Institute, Joydebpur, Gazipur-1701, Bangladesh. E-mail: sultan_palbari@yahoo.com

Received: 24 November 2016/Accepted: 05 December 2016/ Published: 29 December 2016

\begin{abstract}
The study was made on testing purity of different marketed brands of three insecticide groups such as quinalphos, malathion and fenitrotion in the Pesticide Analytical Laboratory under Division of Entomology, Bangladesh Agricultural Research Institute (BARI), Gazipur using suitable protocols GC-FID. Nineteen marketed brands of these insecticides collected form dealers or retailers of Jessore, Gazipur and Rangpur region were analyzed and estimated their purity in two seasons of 2006-2007 and 2007-2008. In these two seasons, among five marketed brands of Malathion, only one brand (MTF) had 98.95-100\% purity which was collected from Jessore in 2007-08 and Gazipur in both the seasons and considered to be standard or acceptable product, but in other regions, this brand contained less $\mathrm{AI}$ and was found to be $<95 \%$ pure which was considered as substandard product. The remaining brands contained 22-92\% purity including SRL and MTX having small amount of AI (22-44\% purity) and all these were unacceptable and impure. Fenitrothion with five marketed brands showed $\geq 96 \%$ purity only in SMT brand in Gazipur and Jessore in 2006-07 and in all the three locations in 2007-08 seasons and this brand considered as standard product. The other four brands of this insecticide had purity at substandard level in all locations in two seasons. Quinalphos with 8 marketed brands, only MLX in 2006-07 and BLX in 2007-08 seasons in all locations had $\geq 95 \%$ purity which was standard product. ALX and CRX in 2006-07 were almost similar and close to MLX except one location, CRX in Gazipur and ALX in Jessore but these two brands were substandard and impure (65-86\%) in next season in all locations. The other brands (KNX, QNP, VNR and SLX) were also substandard and impure having 59\% to 87\% purity.
\end{abstract}

Keywords: insecticides; quinalphos; malathion; fenitrothion; purity

\section{Introduction}

Pesticides are one of the major components of plant protection for the farmers of Bangladesh. It will be impossible to grow good quality crops and also the yield would be down by $30-40$ percent without the use of pesticides. It is assumed that if pesticides are not used for the management of insect pests and diseases, Bangladesh would lose around 4 million tons of food grains and vegetables every year (Hasanuzzoha, 2004). It is known that there are no practical alternative crop protection technologies which can ensure the substitute for agrochemicals to control the majority of pests, diseases and weeds (Finney, 1990). As there is no other sustainable methods of controlling crop pests, the commercial farmers are depend on the use of insecticides to control insect pests. It was understood from farmers' interview that they use insecticides irrationally and indiscriminately (Anonymous, 2001; Ahmed et al., 2005). Pesticide usage for agriculture in developing countries is constantly increasing, and was estimated to be 36-40\% of the world total in 1975 (Alabaster, 1981). Pesticide consumption in Bangladesh has increased day by day as 758 metric tons in 1960 and 3028 metric tons in 1980 to over 19000 metric tons in 2000 (Hasanuzzoha, 2004). The growth rate analysis of pesticide consumption in a period of 24 years shows an average of 9.0\% annual increase (Ali, 2004). In the year 2007, 
over 37,712.20 tones of pesticides were being sold in Bangladesh (Anonymous, 2007). Although field control failure may result from the presence of resistant individual, inappropriate selection of insecticides and doses, poor spray timing and inadequate spray coverage (Phillips et al., 1990), it might also be due to impurity and adulteration of the used insecticides. In Bangladesh, it is assumed that impurity of pesticide is one of the major causes of extensive use of pesticide. Sub standard or little amount of active ingredient (AI) in the formulated pesticides, does not work against insect pests and diseases and the farmers use more pesticide for better result. Impurity and adulteration may be one of the reasons of over and repeated use of pesticides in crops as well as decline in efficacy of applied insecticides (Anonymous, 2009). Considering this, the present study has been initiated to analyze the marketed brands of insecticides for their purity determination and to assure the active materials prescribed in the levels of bottles or packets.

\section{Materials and Methods}

The purity testing was conducted exclusively in the Pesticide Analytical Laboratory, BARI, Gazipur during 2006 to 2008. The samples were collected from Jessore, Gazipur and Rangpur region where vegetables were grown commercially.

\subsection{Materials used in insecticide analysis}

\section{Insecticides:}

Three insecticides such as malathion, fenitrothion and quinalphos belonging to organophosphorous class all being EC formulation, showing below the technical information in connection with their analysis.

\section{Malathion 57EC}

Common name: Malathion (Anonymous, 2000)

Chemical abstract name: Dimethyl [(dimethoxyphosphinothioyl) thiobutanedioate]

Molecular formula: $\mathrm{C}_{10} \mathrm{H}_{19} \mathrm{O}_{6} \mathrm{PS}_{2}$, Mol. wt. 330.3

Available tested brands: MTF, MTX, ZTN, FNN, HTN, SRL.

Mode of action: Non-systemic insecticide and acaricide with contact, stomach and respiratory action.

\section{Fenitrothion 50EC}

Common name: Fenitrothion (Anonymous, 2000)

Chemical abstract name: $O, O$-dimethyl $O$-(3-methyl-4-nitrophenyl) phosphorothioate),

Molecular formula: $\mathrm{C}_{9} \mathrm{H}_{12} \mathrm{NO}_{5} \mathrm{PS}$, Mol. wt. 277.2

Available tested brands: SMT, SVT, EMT, FNX, LTN.

Mode of action: Non-systemic insecticide with contact and stomach action.

\section{Quinalphos 25EC}

Common name: Quinalphos (Anonymous, 2000)

Chemical abstract name: $O, O$-diethyl $O$-2-quinoxalinyl phosphorothioate)

Molecular formula: $\mathrm{C}_{12} \mathrm{H}_{15} \mathrm{~N}_{2} \mathrm{O}_{3}$ PS, Mol. wt. 298.3

Available tested brands: KNX, CRX, MLX, ALX, BLX, SLX, VNR, QNP.

Mode of action: Insecticide and acaricide with contact and stomach action. By penetrating the plant tissues through translaminar action, exhibits a systemic effect.

Chemicals: In the analysis of the insecticides different types of chemicals were used. These are: Acetone, nhexane, Methanol, Acetonitrile and Insecticide Standard.

Glass wares: Pipette, Beaker, Conical flask, Syringe and Vials with septum.

Others: Spatula, PTFE filter, Knife, Scissors, Forceps, Zipper bag, Zip Stick, Teflon stopcock, Para film, Aluminium foil etc.

\subsection{Analytical apparatus used in insecticide analysis}

Gas Chromatograph, Model: Shimadzu GC-2010, Auto Injector AOC 20i, Ultrasonic Bath, Ultra low refrigerator, Ultra pure Water Distillation with Deionizer and Reservoir, Vortex Mixture, Solvent Dispenser, Degassing set, Digital Balance and Computer. 


\subsection{Purity testing}

The available brands of tested insecticides were collected from local market of Jessore, Rangpur and Gazipur region where extensive usage of pesticides was recorded. The brands were selected on the basis of their class, mode of action and demand among the farmers from survey and research reports of eight different locations including Jessore, Rangpur, Gazipur in Bangladesh (Kabir et al., 1996; Anonymous, 2001; Ahmed et al., 2005). All of the formulated products were liquid and dissolved in the respective solvent. The solvents were selected on the basis of the criteria described by Lehotay and Mastovska (2004). The brands of these insecticides varied in two years with at least five brands in each insecticide were tested. There were nineteen brands of three tested insecticides showing individual batch number and expiry date but not mentioning manufacture date in all brands on the label. The purity tests were conducted before the expiry date of each brand of the insecticides. The solutions of different brands of marketed insecticides were prepared in the pesticide analytical laboratory, Division of Entomology, BARI, Gazipur following the procedure compatible with the respective equipment. For color less liquid insecticide the known concentration of the solutions were prepared directly. Thus known and similar concentrated solutions of each of the standard and formulated insecticides were prepared. Methods for testing different brands with GC-FID was developed by setting the instrument parameters suitable for analyzing concerned insecticide selected on the basis of peak sharpness of the chromatogram and retention time for respective compound. The carrier and makeup gas used in the instrument for analysis was helium during 20062007 and nitrogen was used in 2007-2008 due to availability of gases. The instrument parameters of Gas Chromatography set for analysis of each group of insecticide are listed in Tables 1 and 2.

Table 1. The instrument parameters of GC-2010 set for analysis of different group of insecticide during 2006-2007.

\begin{tabular}{|c|c|c|c|c|c|c|c|}
\hline Pesticide group & Detector & Solvent & Temperature & Carrier gas & Make up gas & Injector & $\begin{array}{l}\text { Inj. } \\
\text { vol. }\end{array}$ \\
\hline Malathion & FID & Hexane & $\begin{array}{l}\text { Column- } 180^{\circ} \mathrm{C} \\
\text { Injection port- } 200^{\circ} \mathrm{C} \\
\text { Detector- } 240^{\circ} \mathrm{C}\end{array}$ & Helium & Helium & Auto & $1 \mu \mathrm{l}$ \\
\hline Fenitrothion & FID & Hexane & $\begin{array}{l}\text { Column- } 180^{\circ} \mathrm{C} \\
\text { Injection port- } 200^{\circ} \mathrm{C} \\
\text { Detector- } 250^{\circ} \mathrm{C}\end{array}$ & Helium & Helium & Auto & $1 \mu 1$ \\
\hline Quinalphos & FID & Hexane & $\begin{array}{l}\text { Column- } 180^{\circ} \mathrm{C} \\
\text { Injection port- } 200^{\circ} \mathrm{C} \\
\text { Detector- } 230^{\circ} \mathrm{C}\end{array}$ & Helium & Helium & Auto & $1 \mu \mathrm{l}$ \\
\hline
\end{tabular}

Table 2. The instrument parameters of GC-2010 set for analysis of different group of insecticide during 2007-2008.

\begin{tabular}{llllllll}
\hline $\begin{array}{l}\text { Insecticide } \\
\text { group }\end{array}$ & $\begin{array}{l}\text { Detec } \\
\text { tor }\end{array}$ & Solvent & Temperature & $\begin{array}{l}\text { Carrier } \\
\text { gas }\end{array}$ & $\begin{array}{l}\text { Make up } \\
\text { gas }\end{array}$ & Injector & $\begin{array}{l}\text { Inj. } \\
\text { vol. }\end{array}$ \\
\hline Malathion & FID & Hexane & $\begin{array}{l}\text { Column- } 185^{\circ} \mathrm{C} \\
\text { Injection port- } 200^{\circ} \mathrm{C}\end{array}$ & Nitrogen & Nitrogen & Auto & $1 \mu \mathrm{l}$ \\
Fenitrothion & FID & Hexane & $\begin{array}{l}\text { Detector- } 220^{\circ} \mathrm{C} \\
\text { Column- } 190^{\circ} \mathrm{C} \\
\text { Injection port- } 220^{\circ} \mathrm{C}\end{array}$ & Nitrogen & Nitrogen & Auto & $1 \mu \mathrm{l}$ \\
Quinalphos & FID & Hexane & $\begin{array}{l}\text { Detector- } 250^{\circ} \mathrm{C} \\
\text { Column- } 200^{\circ} \mathrm{C} \\
\text { Injection port- } 220^{\circ} \mathrm{C} \\
\text { Detector- } 240^{\circ} \mathrm{C}\end{array}$ & Nitrogen & Nitrogen & Auto & $1 \mu \mathrm{l}$ \\
\hline
\end{tabular}

Before the injection of the solutions of formulated products, standard solutions of each pesticide group were injected with the set instrument parameters. Each peak of the chromatogram for formulated products was characterized by the retention time of the concerned standard solution. The similar retention time of the obtained peak of standard solution and the tested brands solution assured the presence of AI (active ingredient) in the tested brands. Sample results were expressed in ppm automatically by the GC software by comparing the peak area of formulated products with that of standard solution. This result represented the actual amount of AI present in different marketed brands and the purity percentage was determined by comparing it with the amount of AI actually required in the concerned insecticide using the following formula 
Actual amount of AI present in the insecticide

Purity $(\%)=--------------100$

Amount of AI recommended / required

\section{Results}

The results of this study presented here were the purity test of three commonly used insecticides sold by the traders in the local markets of three regions Jessore, Rangpur and Gazipur under different brands. The results were obtained on the chromatograms in tabular form based on the quantification of active ingredient (AI) of the insecticides. Only one chromatogram of standard solution of three insecticides and one chromatogram of marketed brand of each insecticide are shown in Fig. 1 to Fig.6. In this way the results of other marketed brands were also made by in-built GC-2010 software that could not be mentioned here in detail. The lowest detection limit of malathion and fenitrothion was $0.01 \mathrm{mg} / \mathrm{kg}$ and quinalphos, it was $0.02 \mathrm{mg} / \mathrm{kg}$ in GC-FID.

\subsection{Malathion}

Six marketed brands of malathion, five from each location viz., Jessore, Rangpur and Gazipur were tested with GC-FID to estimate their purity during 2006-07 and 2007-08 seasons. The standard of malathion was characterized by its retention time (Figure 1) and the marketed brands also showed similar retention time (RT) in Figure 2. The purity percentages of different marketed brands of malathion are presented in the Tables 3 and 4.

Table 3. The percentages of active ingredient (AI) and purity of marketed brands of malathion 57EC collected from different locations during 2006-07.

\begin{tabular}{lllllll}
\hline \multirow{2}{*}{$\begin{array}{l}\text { Malathion brands } \\
\text { (Code no.) }\end{array}$} & \multicolumn{2}{c}{ Amount of AI present (\%) at different locations } & \multicolumn{2}{c}{ Purity (\%) at different locations } \\
\cline { 2 - 7 } & Gazipur & Jessore & Rangpur & Gazipur & Jessore & Rangpur \\
\hline MTF & 56.407 & 51.517 & 52.405 & 98.959 & 90.360 & 91.918 \\
HTN & 51.779 & 52.410 & 50.880 & 90.820 & 91.927 & 89.243 \\
MTX & 50.115 & 45.826 & 45.662 & 87.971 & 80.378 & 80.091 \\
FNN & 47.367 & 46.419 & 44.858 & 83.081 & 81.418 & 78.680 \\
SRL & 25.247 & 23.259 & 22.986 & 44.283 & 40.796 & 40.317 \\
\hline
\end{tabular}

Table 4. The percentages of active ingredient and purity of marketed brands of malathion 57EC collected from different locations during 2007-08.

\begin{tabular}{lllllll}
\hline \multirow{2}{*}{$\begin{array}{l}\text { Malathion brands } \\
\text { (Code no.) }\end{array}$} & \multicolumn{2}{c}{ Amount of AI present (\%) at different locations } & \multicolumn{2}{c}{ Purity (\%) at different locations } \\
\cline { 2 - 7 } Gazipur & Jessore & Rangpur & Gazipur & Jessore & Rangpur \\
\hline MTF & 56.929 & 57.00 & 51.053 & 99.875 & 100.00 & 89.546 \\
ZTN & 54.055 & 52.631 & 48.476 & 94.812 & 92.314 & 85.026 \\
HTN & 40.263 & 41.195 & 36.107 & 70.621 & 72.256 & 63.331 \\
FNN & 20.750 & 20.264 & 18.608 & 36.395 & 35.543 & 32.638 \\
MTX & 14.184 & 14.008 & 12.720 & 24.878 & 24.570 & 22.310 \\
\hline
\end{tabular}

During 2006-07, among five brands of malathion, only one brand (MTF) 56.40\% AI which showed 98.959\% purity form Gazipur sample (Table 3). The similar brand of Rangpur and Jessore had purity less than that of sample. The brand HTN had also similar purity ranging from 89.243 to $91.927 \%$ and this was below the standard in respect of purity. The brands MTX and FNN had the purity of $\geq 80 \%$ except the sample of FNN collected from Rangpur. This brand was found to have $<80 \%$ purity. The brand SRL showed $<50 \%$ purity from all the locations and the range of purity was 40.317-44.283\%. In 2007-08, only one brand (MTF) of malathion collected form Gazipur and Jessore had the similar level of purity $(\geq 95 \%)$ which was higher than in the first year. The same brand of Rangpur showed $<90 \%$ purity (Table 4). Although the brand ZTN of Gazipur was found to be $94.812 \%$ pure but the similar brand of two other locations had less purity. This level of purity is considered substandard. The brand of HTN had the purity ranged from 63.331-70.621\% while the brands FNN and MTX were much lower AI and purity of 22.310-36.395\%. These levels could be categorized as below substandard. 


\subsection{Fenitrothion}

Five available brands of fenitrothion from each location as Jessore, Rangpur and Gazipur were tested with GCFID to estimate their purity during 2006-07 and 2007-08 seasons. The RT for the standard of fenitrothion was $6.19 \mathrm{~min}$ (Figure 3) and the formulated brands also showed similar RT proving the presence of fenitrothion (Figure 4). The purity percentages of the formulated brands of this insecticide are presented in the Tables 5 and 6.

Table 5. The percentages of active ingredient and purity of marketed brands of fenitrothion 50EC collected from different locations during 2006-07.

\begin{tabular}{lllllll}
\hline \multirow{2}{*}{$\begin{array}{l}\text { Fenitrothion brands } \\
\text { (Code no.) }\end{array}$} & \multicolumn{3}{c}{ Amount of AI present (\%) at different locations } & \multicolumn{2}{c}{ Purity (\%) at different locations } \\
\cline { 2 - 7 } & Gazipur & Jessore & Rangpur & Gazipur & Jessore & Rangpur \\
\hline SMT & 49.866 & 48.289 & 46.769 & 99.732 & 96.578 & 93.538 \\
EMT & 43.341 & 41.535 & 40.790 & 86.682 & 83.070 & 81.580 \\
FNX & 40.927 & 39.864 & 40.384 & 81.854 & 79.728 & 80.768 \\
LTN & 40.743 & 44.003 & 41.717 & 81.486 & 88.006 & 83.434 \\
SVT & 39.719 & 37.215 & 40.504 & 79.438 & 74.430 & 81.008 \\
\hline
\end{tabular}

Table 6. The percentages of active ingredient and purity of marketed brands of fenitrothion 50EC collected from different locations during 2007-08.

\begin{tabular}{lllllll}
\hline \multirow{2}{*}{$\begin{array}{l}\text { Fenitrothion brands } \\
\text { (Code no.) }\end{array}$} & \multicolumn{2}{c}{ Amount of AI present (\%) at different locations } & \multicolumn{2}{c}{ Purity (\%) at different locations } \\
\cline { 2 - 7 } & Gazipur & Jessore & Rangpur & Gazipur & Jessore & Rangpur \\
\hline SMT & 50.00 & 49.822 & 48.663 & 100.00 & 99.644 & 97.326 \\
LTN & 47.274 & 46.701 & 45.780 & 94.548 & 93.402 & 91.560 \\
EMT & 45.726 & 47.356 & 44.156 & 91.452 & 94.712 & 88.312 \\
FNX & 43.840 & 43.800 & 44.459 & 87.680 & 87.600 & 88.918 \\
SVT & 43.840 & 43.796 & 44.284 & 87.680 & 87.592 & 88.568 \\
\hline
\end{tabular}

SMT of fenitrothion contained almost same amount of AI as in the original product recording over $96 \%$ purity in Gazipur and Jessore but the purity was less in Rangpur in 2006-07 (Table 5). SMT was considered as standard product. The brands EMT, FNX and LTN had the purity of $\geq 80 \%$ except one brand (FNX) that was collected form Jessore. SVT of Rangpur was found to be $81 \%$ pure but the same brand of two other locations had $74.430-79.438 \%$ purity. In $2007-08$, SMT had the similar level of purity ( $\geq 97 \%)$ which was also satisfactory. The purity levels and AI of LTN and EMT were found to better than in 2006-07 (Table 6) but their purity were $<95 \%$. AI and purity of FNX and SVT were similar in all three locations with $87.592-88.918 \%$ purity which were substandard and not acceptable.

\subsection{Quinalphos}

Eight different brands of quinalphos, five from each location viz., Jessore, Rangpur and Gazipur region were tested with GC-FID to know their purity during 2006-07 and 2007-08 seasons. The RT for the standard of quinalphos was 9.67 min (Figure 5). The formulated brands also showed similar RT which proved the presence of quinalphos (Figure 6). The purity percentages of the formulated brands of this insecticide are presented in the Tables 7 and 8.

Table 7. The percentages of active ingredient and purity of marketed brands of quinalphos 25EC collected from different locations during 2006-07.

\begin{tabular}{lllllll}
\hline \multirow{2}{*}{$\begin{array}{l}\text { Quinalphos brands } \\
\text { Code no.) }\end{array}$} & \multicolumn{2}{c}{ Amount of AI present (\%) at different locations } & \multicolumn{3}{c}{ Purity (\%) at different locations } \\
\cline { 2 - 7 } & Gazipur & Jessore & Rangpur & Gazipur & Jessore & Rangpur \\
\hline MLX & 24.068 & 23.680 & 24.882 & 96.272 & 94.720 & 99.528 \\
ALX & 23.805 & 22.768 & 24.347 & 95.220 & 91.072 & 97.388 \\
CRX & 22.887 & 23.740 & 23.870 & 91.548 & 94.960 & 95.480 \\
KNX & 20.995 & 19.432 & 21.965 & 83.980 & 77.728 & 87.860 \\
QNP & 15.302 & 14.831 & 14.970 & 61.208 & 59.324 & 59.880 \\
\hline
\end{tabular}

In 2006-07, the three brands (MLX, ALX and CRX) showed >95\% purity in all locations with some exceptions such as CRX in Gazipur and Jessore and ALX in Jessore (Table 7). The KNX had less AI and QNP had much less AI and as such the purity of these two brands recorded $77.728-87.860 \%$ and $59.324-61.208 \%$ purity in three 
locations. During 2007-08, three new brands including CRX and ALX were tested for AI and purity where $100 \%$ AI and purity were found only in BLX (Table 8). The brands VNR, ALX and SLX had the purity of $\geq 81 \%$ in all locations which were sub standard. The CRX revealed $<70 \%$ purity in all locations. The brand CRX showed more impure than in 2006-07.

Table 8. The percentages of active ingredient and purity of marketed brands of quinalphos 25EC collected from different locations during 2007-08.

\begin{tabular}{lllllll}
\hline \multirow{2}{*}{$\begin{array}{l}\text { Quinalphos brands } \\
\text { (Code no.) }\end{array}$} & \multicolumn{3}{c}{ Amount of AI present (\%) at different locations } & \multicolumn{2}{c}{ Purity (\%) at different locations } \\
\cline { 2 - 7 } & Gazipur & Jessore & Rangpur & Gazipur & Jessore & Rangpur \\
\hline BLX & 24.986 & 25.00 & 25.00 & 99.944 & 100.00 & 100.00 \\
VNR & 21.434 & 21.216 & 21.096 & 85.736 & 84.864 & 84.384 \\
ALX & 21.240 & 21.542 & 21.446 & 84.960 & 86.168 & 85.784 \\
SLX & 20.429 & 20.700 & 20.429 & 81.716 & 82.800 & 81.716 \\
CRX & 16.270 & 16.562 & 16.641 & 65.080 & 66.248 & 66.564 \\
\hline
\end{tabular}

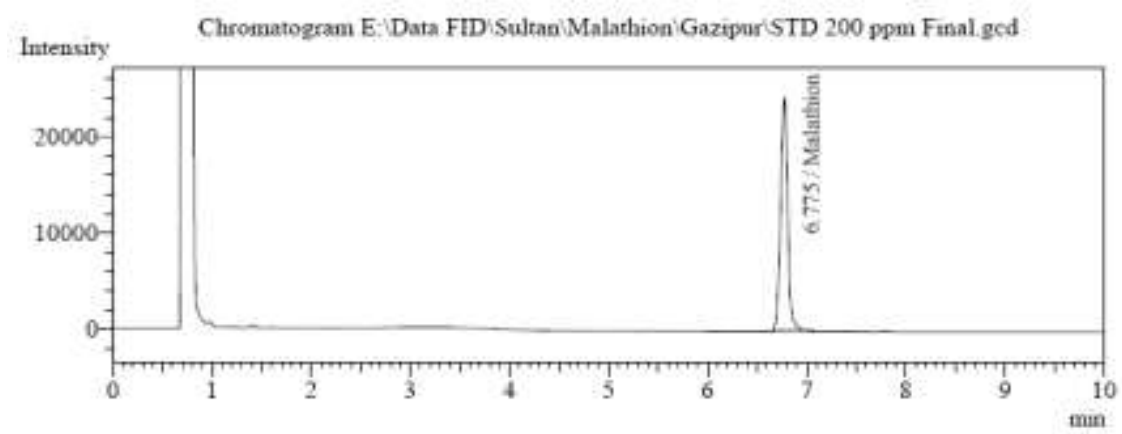

Figure 1. Chromatogram of malathion standard solution.

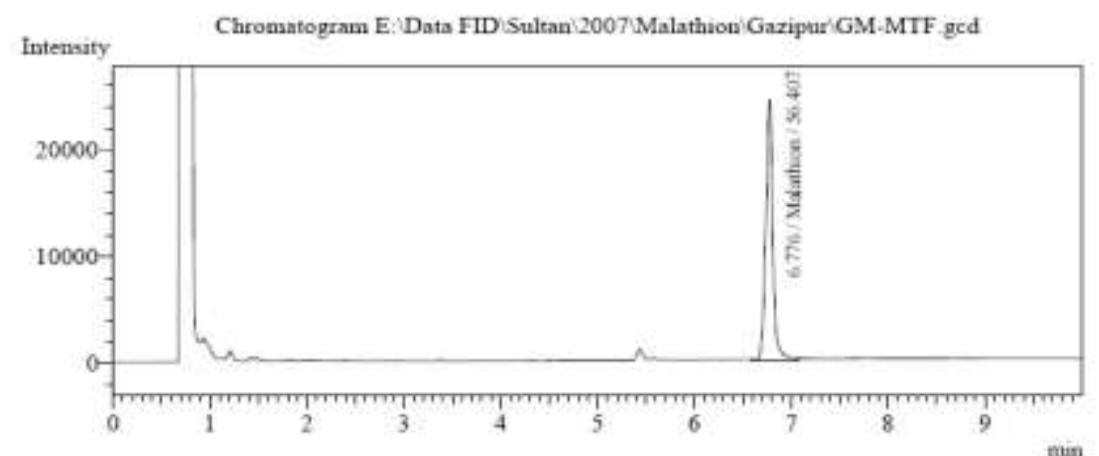

Figure 2. Chromatogram of malathion obtained from the marketed brand of GM-MTF.

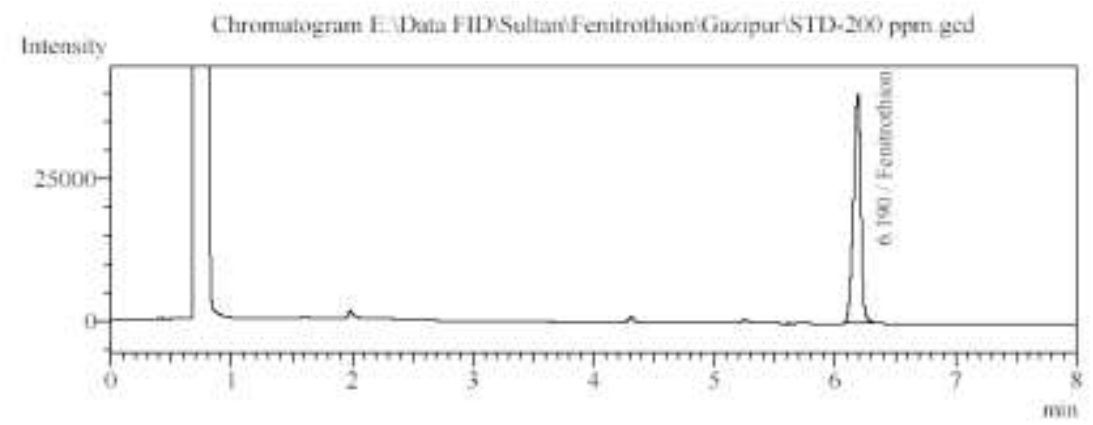

Figure 3. Chromatogram of fenitrothion standard solution. 


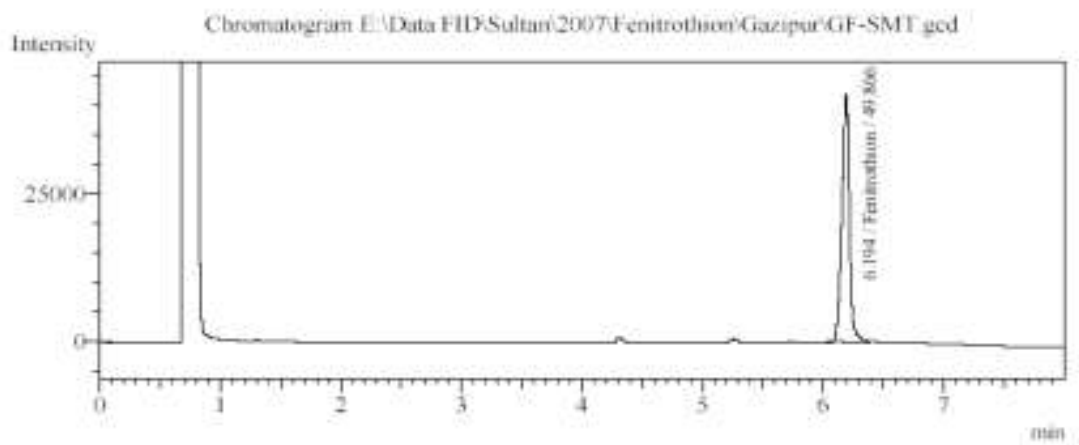

Figure 4. Chromatogram of fenitrothion obtained from the marketed brand of GF-SMT.

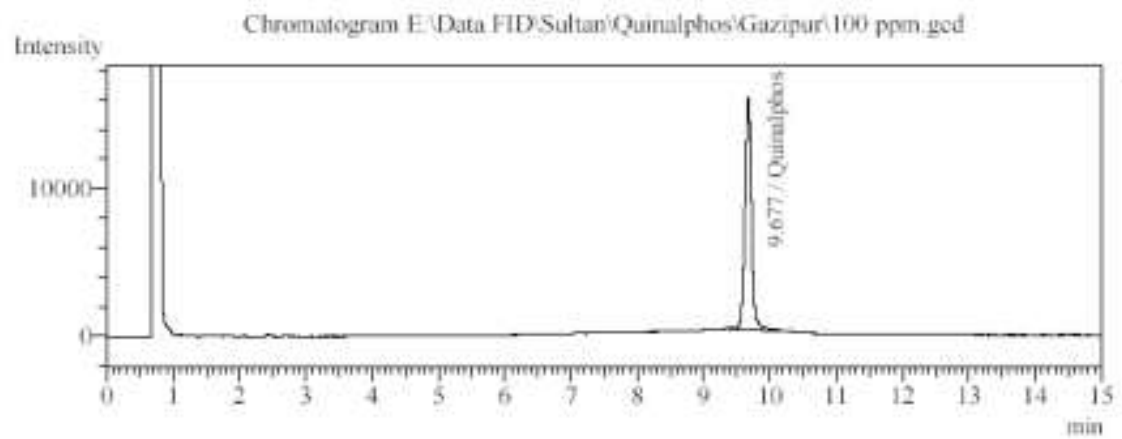

Figure 5. Chromatogram of quinalphos standard solution.

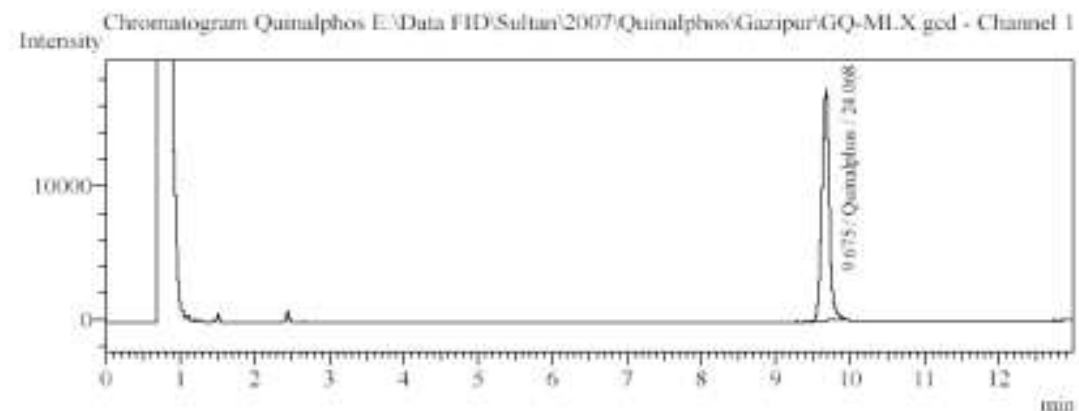

Figure 6. Chromatogram of quinalphos obtained from the marketed brand of GQ-MLX.

\section{Discussion}

The purity of different brands of selected insecticides were classified in to three categories viz., standard or acceptable level $(>95 \%)$, substandard $(<95-80 \%)$ and lower level or little amount $(<80 \%)$ of active ingredient (AI) present in the product. Different brands of three insecticides were collected from dealers of Jessore, Gazipur and Rangpur region and estimated their purity with GC-FID during 2006-07 and 2007-08 seasons. In these two seasons, among six tested marketed brands of malathion only one brand (MTF) had $>98 \%$ purity which was collected from Jessore in 2007-08 and Gazipur in both the seasons and considered to be standard or acceptable product but in other regions this brand contained less AI which was sub standard or unacceptable product. The purity of remaining five brands were 22-92\% including SRL and MTX having little amount of AI (22-44) and all these are unacceptable. Fenitrothion with five marketed brands showed $\geq 96 \%$ purity only in SMT brand in two locations in 2006-07 and all of the three locations in 2007-08 season and this brand might be considered as standard product. The other four brands of this insecticide had purity at substandard level in all locations in two seasons. Of 8 marketed brands of quinalphos the standard brands were MLX in 2006-07 season and BLX in 2007-08 seasons in all locations. These two brands were acceptable level having $\geq 95 \%$ purity. ALX and CRX in 2006-07 were almost similar and close to MLX except in one location, CRX in Gazipur and ALX in Jessore but these two brands were substandard and impure (65-86\%) in next season in all locations. The 
remaining brands of quinalphos such as VNR, KNX and SLX were sub standard, but the QNP was the least in quality and was found below the sub- standard level or unacceptable in both the seasons. But in respect of purity of malathion and fenitrothion with emulsifiable concentration in formulation, quinalphos was more pure in quality. The factors such as packing of insecticide in different formulations, storing period and storage facilities (presence of light, temperature, humidity, etc.) handling and transportation of insecticides might be the probable reasons of different degrees of purity of marketed products. Adulteration could be other reason of impurity. Kabir et al. (2008) reported 8 brands of malathion of which only two brands showed acceptable level of purity $(100 \%)$ and another 5 brands had the purity which was substandard (80.11-93.80\%) but the remaining one showed very poor purity which was only $59.88 \%$. They also found that the purity of three tested brands of quinalphos ranging from $68.34 \%$ to $76.64 \%$ active purity which were lower level $(<80 \%)$ of active ingredient (AI) present in the product. It is reported that some of the marketed brands of malathion and fenitrothion do not contain required amount of active ingredient (Anonymous, 2010). The results of the present study agreed with the works of the above authors.

\section{Conclusions}

The analytical results of three insecticides with nineteen different marketed brands showed variations in purity. Few brands (three brands of quinalphos and one brand of malathion and fenitrothion) of tested insecticides were found at standard level of purity. Most of the brands of the marketed insecticides were below standard or impure in quality. The purity of malathion was poor which contained $<50 \%$ purity in some brands. These levels are unacceptable and below standard. It is, therefore, concluded that improper storage facilities and adulteration might be the cause of reduction of the purity.

\section{Conflict of interest}

None to declare.

\section{References}

Ahmed MS, MA Sardar, MA Haque and KH Kabir, 2005. A survey on the pattern of insecticidal usage for the protection of brinjal (Solanum melongena) from the attack of insect pests in Jessore. Bangladesh J. Zool., 33: 57-63.

Alabaster JS, 1981. Review of the state of aquatic pollution of East African inland water. CIFA Occas, Pap. 9: $35 \mathrm{p}$.

Ali MMMS, 2004. Pesticide uses and food safety. “The Independent” January 30 issue, p. 10.

Anonymous, 2000. The pesticide manual. In: CDS Tomlin (ed.). British Crop Protection Council (BCPC), UK, pp. 3-414.

Anonymous, 2001. Coordinated research on insecticide residue and resistance in major vegetables grown in Bangladesh. Report on Contact Research Project, BARC, BARI, Joydebpur, Gazipur, 102 p.

Anonymous, 2007. Bangladesh Crop Protection Association Sales report 2007, Dhaka, Bangladesh.

Anonymous, 2009. Purity testing of eleven different groups of insecticides. In: Annual Research Report, 20082009. Entomology Division, BARI, Joydebpur, Gazipur, Bangladesh, pp. 142-149.

Anonymous, 2010. Purity testing of ten different groups of insecticides. In: Annual Research Report, 20092010. Entomology Division, BARI, Joydebpur, Gazipur, Bangladesh, pp. 159-165.

Finney J, 1990. World crop protection prospects. Paper presented in Seventh International Congress of Pesticide Chemistry, Hamburg, Germany, August 5-10, 1990.

Hasanuzzoha, 2004. Environment friendly use of pesticides in field crop protection in Bangladesh and pre/post safety measures for farmers, Ph.D. Thesis. IPM Laboratory, Institute of Biological Sciences, University of Rajshahi, Bangladesh, pp. 366.

Kabir KH, ME Baksh, FMA Rouf, MA Karim and A Ahmed, 1996. Insecticide usage pattern on vegetable at farmer level of Jessore region in Bangladesh: A Survey Finding. Bangladesh J. Agril. Res., 20: 241-254.

Kabir KH, MA Rahman, MS Ahmed, MDH Prodhan and MW Akon, 2008. Quantitative analysis of some common insecticides used against vegetable insect pests. Bangladesh J. Agriculturist., 1: 259-264.

Lahotay SJ and K Mastovska, 2004. Evaluation of common organic solvents for gas chromatographic analysis and stability of multi class pesticide residues. J. Chromatography A., 1040: 259-272.

Phillips JR, JB Graves and RG Luttrell, 1990. Insecticide resistance management: relationship to integrated pest management. Pesticide Sci., 27: 459-467. 